\title{
Blockchain and Artificial Intelligence Technologies for Balanced Foreign Trade: Replacing Exchange Function of Money
}

\author{
Mustafa Emre Civelek, PhD \\ Oksan Kibritci Artar, PhD \\ Istanbul Commerce University, Turkey
}

Doi:10.19044/esj.2019.v15n22p137 URL:http://dx.doi.org/10.19044/esj.2019.v15n22p137

\begin{abstract}
Today, the capitalist economy has entered into a dead end. Unemployment is expected to reach an unprecedented level due to the rise of automation and artificial intelligence technologies. The creation of excess fiat money will not be a remedy for the collapse of the capitalist economy. In the future, a new economic model open to government intervention will be needed. Moreover, if global monetary system collapses, government should find a solution to continue foreign trade in order to meet the needs of their citizens. Trade unions are classical means that increase trade among the member countries, but they cause imbalance in mutual trade volumes. The advent of blockchain and artificial intelligence technologies will bring an end to the obsolete and outdated foreign trade methods. These technologies will also lead to the emergence of balanced trade unions across countries. This paper focuses on defining a new system known as intelligent trade matrix, suggesting that this system will allow barter transactions between two countries without imposing any customs duty.
\end{abstract}

Keywords: Artificial Intelligence, Foreign Trade, Blockchain, Balanced Trade, Digital Economy

\section{Introduction}

Participation in economic integration arrangements is a method for countries to grow and revitalize their economies (Balassa, 2013). There are different types of economic integrations starting from preferential tariff agreements to free trade areas and from customs unions to total economic unions (Jovanović, 2007). Types of economic integrations among countries vary according to the degrees of integration (Balassa, 2013). Economic integration under supranational institutions often requires the establishment of free trade areas and the resettlement of tariffs between countries. This means 
that countries give up their protective national barriers. However, this situation has many advantages and drawbacks. Free trade zone member countries, which have comparatively inefficient production facilities, have become dependent on imports and have current account deficit (Burchill Linklater et al., 2013). Under such circumstances, it is unreasonable to reduce the trade barriers completely. Moreover, some countries cannot trade with their national currencies, and this seems to be another relevant problem. This causes a shortage of foreign exchange and erratic exchange rates (Gilpin \& Gilpin, 2001).

Nowadays, foreign trade transactions are still performed by using outdated methods. Despite the adoption of a single window approach in terms of shortening the processes in foreign trade transactions and conducting them under a single roof, a platform that brings together all parties involved in a typical foreign trade transaction has not been created yet (Curbelo \& Penfold, 2014). Today, rapidly developing blockchain and artificial intelligence technologies have created a new hope for the seamless integration of the business processes performed in foreign trade (Hofmann, Strewe, \& Bosia, 2017).

After all, there is a more important problem which is the inevitable collapse of the capitalist economy (Ford, 2009). Unemployment is expected to reach an unprecedented level due to the rise of automation and artificial intelligence technologies (Ford, 2015). The creation of excess fiat money will not be a remedy for the collapse of the capitalist economy (Öz, 2018). In the future, a new economic model open to government intervention will be required (Civelek, 2018). Moreover, if the global monetary system collapses, government should find a solution to continue the foreign trade in order to meet the needs of their citizens. Trade unions countries cause imbalance in mutual trade volumes between the member countries (Kerr \& Gaisford, 2007). The advent of blockchain and artificial intelligence technologies will bring about an end for the obsolete and outdated foreign trade methods. These technologies will lead to the emergence of balanced trade unions across countries. A new system known as intelligent trade matrix was suggested in this paper. In this system, barter transactions between two countries can be performed without imposing any customs duty. This solution also decreases the need for foreign currency. The companies which are the member of this system must use new electronic currency issued by the system and the value of this electronic currency can be determined by artificial intelligence.

The establishment of such a system is primarily possible with the replacement of the conservative paper-based foreign trade documentation by its electronic counterparts. The design of the single foreign trade document, which collects all of the functions and thus ensures that the processes are integrated, is primarily required. Use of artificial intelligence on fully 
integrated system will lead to full automation and also promote the use of barter system. Intelligent trade matrix is an important pillar of the proposed strategy to accelerate the transition to the sharing and abundance economy. According to this strategy, the need for human intervention to the business processes should completely be eliminated (Civelek, 2018).

In this study, first of all, blockchain and artificial intelligence technologies were mentioned. Subsequently, paperless foreign trade concept was explained. Economic gridlock in the Post-Digital Ecosystem was tried to explain. Afterwards, trade union concept was explained and some solution was recommended to replace exchange function of money.

\section{Blockchain and Artificial Intelligence Technologies and Paperless Foreign Trade}

Blockchain is a peer to peer technology which allows one to write information on a ledger kept at the same time on different computers over a distributed network (Dannen, 2017). The structure of blockchain consists of a chain of consecutively encrypted blocks which are linked together (Singhal, Dhameja, \& Panda, 2018). A blockchain is able to record information by means of digital signatures and cryptographic hashing (Hill, Chopra, \& Valencourt, 2018). Artificial Intelligence is a branch of science that concentrates on the perception, reasoning, and learning capabilities of computers (Bar-Cohen, Marom, \& Hanson, 2009). Blockchain and artificial intelligence are disruptive technologies and they are expected to cause radical changes in current business processes. Foreign trade processes will also be affected by these new technologies.

Key action in establishing intelligent trade matrix is the digitalization of the classic business processes of foreign trade transactions. In order to combine all the parties which are involved in a foreign trade transaction, the use of single electronic document instead of classical paper documents is crucial. All the functions of classical paper documents should be combined in a single electronic document (Civelek \& Seçkin, 2017). Combination of all trade documents into a single universal foreign trade document will lead to the integration of the processes. This kind of online documents that allow such multi-party use is suitable for the philosophy of blockchain (Civelek \& Özalp, 2018). Owing to block chain technology, transactions can be carried out without the need of a trusted third party. The combination of the idea of a single document and blockchain technology will lead to radical changes in the integration of multilateral business processes. Blockchain technology is expected to provide a significant cost reduction in the supply chain business process and eliminate time losses (Singhal, Dhameja, \& Panda, 2018). Therefore, studies on the use of blockchain technology in supply chain have increased. Recent projects are generally focused on blockchain-based 
electronic bill of lading and similar documents, and payment methods such as letters of credit, etc. Yet, in the processes of foreign trade business conducted electronically, there is no need to issue separate documents for each transaction and the functions of all documents can be integrated into a single document (Civelek, Çemberci, Uca, Çelebi, \& Özalp, 2017). The multilateral decentralized structure of blockchain technology also supports this argument.

Due to its disruptive potential (Singhal, Dhameja, \& Panda, 2018), blockchain technology is known as the second Internet revolution (Bashir, 2017). Hence, it forces the paradigms in business life to shift (Harrison, 2015). Blockchain technology will facilitate the studies on full integration of the business processes in foreign trade (Civelek \& Özalp, 2018). Blockchain technology also allows the elimination of trusted third party (Brando et al., 2018). Therefore, it is expected that integrated single document has a tamper proof structure without any requirement of an intermediary authority (Drescher, 2017). However, before the advent of blockchain technology, there was the need of a centralized authority to bring together all the parties involved in a particular foreign trade transaction. By implementing artificial intelligence technologies into this integrated single document, some transactions can be executed autonomously (Civelek \& Seçkin, 2017). Using both technologies (blockchain and artificial intelligence) together will make it possible to pave the way for full integration. These disruptive technologies may bring an end to the paper documents and complex business processes. More secure but simple payment methods may be developed by using blockchain technology (Karame \& Androulaki, 2016). In these new payment methods, traditional foreign trade documents (i.e., Bill of Lading, Invoice, Certificate of Origin, Analysis Certificate, and Packing List, etc.) may be replaced by a single electronic document which has multiple purposes. Finally, removing a large number of foreign trade documents leads to the facilitation of trade. All the parties involved in a foreign trade transaction may be connected on a single platform and they can conduct the processes on an integrated single electronic document. On this integrated platform, artificial intelligence also allows the transaction to be performed without any human intervention. This platform can be referred to as the intelligent trade matrix. Through the integration of the intelligent trade matrix system with the autonomous logistics and warehouse applications, seamless integration and tracking in the transportation will be realized. By means of the internet of things technologies, all physical items in supply chain will be connected to the intelligent trade matrix system. Accordingly, artificial intelligence will be able to realize all these processes in the most optimum way without the need of any human intervention. 


\section{The Role of Money in the Post-Digital Ecosystem}

The basic functions of money are as follows: it is a store of value, a measure of value, and a means of exchange (Petry, 2008). In the post-digital ecosystem, productivity increases due to the automation and artificial intelligence technologies. Subsequently, an increase in productivity eventually leads to an increase in unemployment. Consequently, the purchasing power of consumers decreases. This vicious cycle continues to loop until the collapse of the current economic system. As a palliative treatment, excess fiat money has been created and personal debt ratio of the consumers has been raised (Civelek, 2018). The ratio of personal debt to disposable income has doubled over the last three decades (Foster \& Magdoff, 2009). However, this monetary balloon only postpones the bitter end. Eventually, this balloon will explode and all the fiat money will be worthless (Hastie \& Dawes, 2010). Digitization of money triggered the change. Nevertheless, classical money may remain in circulation for many years, but people's perception of money will change and at the end of turbulence in the global economy, other means to substitute for money will inevitably be found. The rise of the sharing economy will accelerate the change in the perception of money. In future sharing economy, production facilities that have decentralized collective structures will come up (Rifkin, 2014). After the collapse of the capitalist economy, the importance of capital as a production factor will diminish. Amidst these developments, the importance of knowledge as production factor is rising (Maier, 2007). In digital economy, knowledge is considered to be the most important production factor (Civelek, 2009). The diminishing importance of capital causes the individual and collective production to increase. Production will not be profitable enough for the capital owner. Therefore, government will have to intervene in economic activities. The ownership of production facilities shifts from capital owners to collective entities as government increase their influence over the economy. In addition to all these, companies will change their capital structure by implementing token economy and crowd financing.

Today, productivity increases unprecedentedly owing to unmanned production by automation technologies and artificial intelligence. Moreover, renewable free energy, ultra-cheap and effective transportation facilities, and $3 \mathrm{D}$ printers decrease the cost of production. However, on the other side of the coin, unemployment will increase unprecedentedly. Unemployment and ruthless inequality in the post-digital ecosystem would impose indirect pressure on the profitability of enterprises. The intervention of the government in the economy and production will be inevitable to break this vicious circle. The capitalist system in the world will be replaced by the mixed economy working under the auspices of the government. Collectivism and government intervention will be important elements of the new economic system. Today, as the production method changes, it would cause a sudden tectonic shift in 
the social and economic structure. This tectonic shift would be triggered by an unprecedented global economic crisis. In the post-digital ecosystem, unemployment will be widespread. From an optimistic point of view, there would be no need to work in the future abundance economy. Yet, being needless can be regarded as a disease which inflects humanity (Keynes, 1931). Sharing economy is considered to be an alternative to the capitalist economy. Some researchers refer to the new alternative system as crowd-based capitalism (Sundararajan, 2016). No matter what name is used, when changing the economic system, the excess fiat money may be revoked and extracted from the economic system. It is probable that classical money will be null and void. Recently, the signs of the new economic system have emerged in the application areas of blockchain technology like decentralized alternative to banking system. If third party intermediaries and controllers such as banks and government are eliminated from the system, the money perception will radically change as well (Girasa, 2018).

\section{Trade Unions and Balanced Trade}

International economic integrations refer to the liberalization of trade and other economic relations among countries provided that mutual interests of the countries involved are safeguarded (Şanl, 2008). The primary aim of economic and trade integrations is to make the allocation of resources more efficient in the long run by contributing to economic growth in the countries. In this regard, many countries head towards alliances with one another in order to retain advantage on the global scale in the developing and changing world economy by reinforcing the economic and trade relations among them. Developing countries which cannot keep up with the production paces of the developed countries are involved in attempts of industrialization; and thus through merges in their domestic markets, they head towards forming integrations both in the economic area and trade (Uyar, 2007).

Subsequently, various steps are being taken so that trade between the countries can be facilitated by Free Trade Agreements based on the treaty of the World Trade Organization (WTO). The aims initiated by such steps are to develop the relations of the member countries in trade and economy, to maintain the sustainability of the scarce world resources, and to eliminate barriers in international trade by enhancing the resources that are possessed by the countries (Alkin \& Gürlesel, 2010).

Attempts of countries to realize trade liberalization reflect development in two ways. The first one is through the General Agreement on Tariffs and Trade (GATT) and the second one is through Regional Economic Integrations. GATT foresees the reduction of the countries' custom tariff and other trade related restrictions so as to eliminate the barriers that lie in the way of world trade. The second way of attempts initiated to render world trade 
liberal is through Economic Integrations which aim to facilitate trade among countries which have geographical proximity to one another. Thus, the aspiration to be strong in terms of markets under global conditions has gained more prominence. The most successful economic integration movement of the world is that of the European Union (EU) which took place in Europe following World War II (Şanlı, 2008).

The leading economic integrations that aim at trade facilitation are as follows: European Union (EU), European Free Trade Association (EFTA) and North American Free Trade Agreement (NAFTA), which are among the integration movements realized among developed countries. Besides these, there are also Asia-Pacific Economic Cooperation (APEC), Black Sea Economic Cooperation (BSEC) and the Organisation of Islamic Cooperation (OIC), which are the integration movements among the developing countries (İyibozkurt, 1995). Another type of integration is seen in the "Free Trade Zones" which involves the abolishment of customs duties among member countries and imposing specific customs tariff that has been implemented previously by each country to the countries that are not parties of the agreement (Yiğit, 2003). EFTA, Latin American Free Trade Association (LAFTA) established by countries in Latin America and European Economic Area (EEA), are among the examples of such integrations (Uyar, 2007).

A further integration type among the free trade zones is the "Customs Union" which abolishes the imposing of customs duties on the member countries and also imposes a common customs policy on the third countries (Kara, 1996). Customs unions ensure an increase in trade and consequently an increase in trade revenues. In this way, they have a role in accelerating economic development. Markets which did not use to experience competition prior to the integration begin to realize more efficient production for competitive advantage following the customs union integration. By doing so, the welfare levels of market players increase and the production costs decrease, which allows for the increase in economic efficiency in parallel with the developing technology (Y1ldirim, 2005).

Economic Union is the last phase of the economic integration process. It is considered to be a more advanced integration type compared to the common market and requires the harmonization of national policies. By integrating their monetary, fiscal and socio-economic policies, the countries were able to establish a sort of economic union through this way (Ertürk, 2006). Another component of the Economic Union is the Monetary Union whose foundation of economic integration involves a system with a single currency, central bank and harmonization of a common fiscal system, and foreign trade policies (Uyar, 2007).

It is observed that the use of information and communication technologies has increased in recent years, which has brought about a rise in 
the factors that promote international trade, and the internet has caused an upward trend in the trade figures of the countries (Artan \& Kalayc1, 2009). Although the world has gained familiarity, yet it has been shaped by technological innovations and a new technology known as Blockchain, which enables the sharing of information in a secure and transparent way. This technology creates a positive impact on the trade transactions by strengthening the individuals and companies in the world while ensuring that the transactions are performed in a more productive, economical, and rapid way. The rapid development of communication technologies has necessitated that parties should become aligned with this situation in international trade and some rules have to be changed in line with such a change. Through the rules established by the International Chamber of Commerce (ICC), some practices such as means of payment by letter of credit have started to enter into the regulations of the countries in order to facilitate international trade for the countries (Yurtsever, 2010). As a result of the development of information and communication technologies, the use of the internet has increased and it is foreseen that the exports of the countries will be developed further owing to the reduced trade costs in the area of international trade (Bojnec \& Fertö, 2009). Yet, it is observed that while countries that have different levels of economic development exploit technology intensively, countries with low income levels cannot benefit thoroughly from the trade facilitation enabled by such technologies (Chinn \& Fairlie, 2007; Yadav, 2014). The trade openness of the countries also has a role in the impact of digital transformation on international trade. It has been observed that the trade openness rate of the countries has a positive and significant impact on the internet use and economic growth (Clarke \& Wallstein, 2006; Meijers, 2014).

Studies are under way for Blockchain-based integrations across the globe. In recent times, Kenya, the Republic of Korea, and England have been involved in similar endeavors. In addition, an electronic certificate of origin was included into the system through a pilot project that utilized Blockchain for the Common Market for Eastern and Southern Africa (COMESA) in February 2018, which established a real-time blockchain platform for the parties involved (Mbogo, 2018).

Within this scope, there is a great deal of work in the literature regarding the fact that digitalization can facilitate trade for the member countries of integration. Bojnec and Fertö (2009) analyzed the bilateral merchandise export among the OECD countries. In their study, they demonstrated that internet use reduced trade costs and results in increased competition, while manufacturing industry boosted export volume. Timmis (2012) analyzed the impact of internet use on the international trade among the OECD countries through the gravity model. The results of the study reveal 
that the countries which have an intensive use of the internet have more trade relations compared to other countries.

In their study, Artan and Kalaycı (2009) conducted a research for 30 OECD countries in which Turkey was also included. It was observed that gross domestic product, representing the size of the countries' economy over a specific time period, is an important determiner of international trade and it has a positive impact on trade among the countries. K1z1ltan and Sandalcilar (2011) analyzed the comparative advantage of Turkey in the Economic Cooperation Organization (ECO) region in terms of foreign trade. The results of their study reveal that Turkey, in her trade with the ECO region, based on the Standard International Trade Classifications (SITC), has comparative advantage in the following sectors: "Animal or Vegetable Fats and Oils, Candles", "Machinery and Transport Equipment", "Beverages and Tobacco", "Miscellaneous Manufactured Articles", "Chemicals and related products, n.e.s. (not elsewhere specified)", "Food and Live Animals", "Crude materials, inedible, except fuels", and "Mineral Fuels, Lubricants and Related Materials".

Lee (2012) applied regression analysis within the context of the gravity model in order to evaluate trade among the countries based on the data belonging to 23 of the OECD countries. The results indicate that the internet is significant and it is the most important element in the manufacturing and service sector. In another study, Dolu and Göksel (2017) examined the change in the per capita income of Mexico and in the export and import data realized with the USA following the launching of NAFTA. The authors attempted to answer the question "If NAFTA had not been signed, what would the per capita income and foreign trade data of Mexico be?" by a synthetic control method, constructing a synthetic Mexico. The findings of the analysis demonstrate that after the launching of NAFTA, there was a considerable increase in the export and import data of Mexico with the USA. Nevertheless, this had a negative impact on the per capita income of Mexico.

Blockchain may increase productivity in exports by allowing a realtime, completely transparent, and secure interaction for all the related parties while enabling the trade transactions to be conducted in a more effective way by eliminating the intermediaries. Transactions can be monitored by everyone and by using smart agreements, they become automatic. Thus, the reduced costs will provide benefits for all members of the union. The International Chamber of Commerce (ICC) states that the export of developing countries, in particular, can increase by $80 \%$ owing to the blockchain-based integration (International Chamber of Commerce, 2017). 


\section{Conclusion}

Barter is the oldest method of trade. Therefore, it is a natural substitute for money. On the new generation online platform, the use of electronic tokens instead of money would be possible. This system also allows the elimination of customs duty in barter transaction mutually. Additionally, this system contains an artificial intelligence system to balance the emission of electronic token in order to prevent decrease in value. By the use of single electronic documents and artificial intelligence on this system, the need for human intervention in the business processes may completely be eliminated. By means of integration of the internet of things technology into this system, transportation charges will decrease to the minimum level and also customs integration will be crucial due to the elimination of waste of time. This holistic approach causes an unprecedented level of efficiency. Consequently, this system starts to dominate all aspects of foreign trade. Therefore, this preferred system is referred to as the intelligent trade matrix. Intelligent trade matrix may replace exchange function of money after a while. On this system, blockchain technology replaces the function of the bank. Owing to its decentralized structure, there is no need for central authority to build trust between the trading partners. This feature also allows the issuing of a trusted electronic currency on the system. Therefore, this system probably leads to the dependence on the foreign currency to conduct foreign trade. In the future, using this system would be a remedy for the shortage of foreign exchange and erratic exchange rates.

\section{References:}

1. Alkin, K. \& Gürlesel, F. (2010). Avrupa Birligi'nin Serbest Ticaret Anlaşmalarına Türkiye'nin de Dahil Edilmesi, İTO Yayınları.

2. Artan, S. \& Kalayc1, C. (2009). İnternetin Uluslararası Ticaret Üzerindeki Etkileri: OECD Ülkeleri Örneği, Doğuş Üniversitesi Dergisi, 10 (2), 175-187.

3. Balassa, B. (2013). The Theory of Economic Integration. Abingdon: Taylor \& Francis.

4. Bar-Cohen, Y., Marom, A., \& Hanson, D. (2009). The Coming Robot Revolution: Expectations and Fears About Emerging Intelligent, Humanlike Machines . New York: Springer.

5. Bashir, I. (2017). Mastering Blockchain . Mumbai: Packt Publishing.

6. Bojnec, S. \& Ferto, I. (2009). Agro-food Trade competitiveness of Central European and Balkan countries. Food Policy, Elsevier, vol. 34(5), 417-425. 
7. Brando et al. (2018). A Smart City's Model Secured by Blockchai. In J. Mejia, M. Munoz, \& et al., Trends and Applications in Software Engineering (249-261). New York: Springer.

8. Burchill, S., Linklater, A., et al. (2013). Theories of International Relations. New York: Palgrave Macmillan.

9. Civelek, M. (2018). Humans of Machine Age: Management Strategies for Redundancy. Journal of Industrial Policy and Technology Management, 1(2), 87-98.

10. Civelek, M. E. (2009). İnternet Çă̆ Dinamikleri. İstanbul: Beta Basim.

11. Civelek, M. \& Özalp, A. (2018). Blockchain Technology and Final Challenge for Paperless Foreign Trade. Eurasian Business \& Economics Journal, 15(1), 1-8.

12. Civelek, M. \& Seçkin, N. (2017). Paperless Trade: Evaluation of the Current Situation \& towards the Integrated Single Foreign Trade Document. Journal of Management Research, 9(2), 1-10.

13. Civelek, M., Çemberci, M., Uca, N., Çelebi, Ü., \& Özalp, A. (2017). Challenges of Paperless Trade: Redesign of the Foreign Trade Process and Bundling Functions of Traditional Documents. International Business Research, 10(2), 74-81.

14. Chinn Menzie, D. \& Robert, W. F. (2006). ICT Using in the Developing World: An Analysis of Differences in Computer and Internet Penetration, NBER working paper, 2382.

15. Clarke, G.R.G. \& Scott J.W. (2004). Has the Internet Increased Trade? Evidence from Industrial and Developing Countries, World Bank Policy Research Working Paper, 3215.

16. Curbelo, J. \& Penfold, M. (2014). International Trade Single Window. Requirements for a successful implementation in Latin America. Corporación Andina de Fomento.

17. Dannen, C. (2017). Introducing Ethereum and Solidity. New York: Apress.

18. Dolu, A. and Göksel, T. (2017). Nafta'nın Meksika Ekonomisi Üzerindeki Etkileri: Sentetik Kontrol Metot Yaklaşımı. Süleyman Demirel Üniversitesi İktisadi ve İdari Bilimler Fakültesi Dergisi, 22(3), 915-926.

19. Drescher, D. (2017). Blockchain Basics: A Non-Technical Introduction in 25 Steps. New York: Apress.

20. Ertürk, E. (2006). Uluslararası İktisadi Birleşmeler, 4.Bask1, Alfa Aktüel Yayınları, İstanbul.

21. Ford, M. (2009). The Lights in the Tunnel: Automation, Accelerating Technology and the Economy of the Future. Acculant Publishing. 
22. Ford, M. (2015). Rise of the Robots: Technology and the Threat of a Jobless Future. New York: Basic Books.

23. Foster, J. \& Magdoff, F. (2009). The Great Financial Crisis: Causes and Consequences. New York: Monthly Review Press.

24. Gilpin, R. \& Gilpin, J. (2001). Global Political Economy. Princeton: Princeton University Press.

25. Harrison, G. (2015). Next Generation Databases: NoSQLand Big Data. New York: Apress.

26. Hastie, R. \& Dawes, R. (2010). Rational Choice in an Uncertain World. London: SAGE.

27. Hill, B., Chopra, S., \& Valencourt, P. (2018). Blockchain Quick Reference: A guide to exploring decentralized blockchain application development. Mumbai: Packt Publishing.

28. Hobikoğlu, E.H. (2007). Gümrük Birliklerinin Ekonomik Etkileri ve Türkiye Ekonomisi: Gümrük Birliği Yansımaları. Sosyal Bilimler Dergisi, (1), 65-82.

29. Hofmann, E., Strewe, U., \& Bosia, N. (2017). Supply Chain Finance and Blockchain Technology. New York: Springer.

30. International Chamber of Commerce (2017). Rethinking Trade and Finance, Paris:ICC.

31. İyibozkurt, E. (1995). Uluslararası İktisat, 3.Bask1, Ezgi Kitabevi, Bursa.

32. Jovanović, M. (2007). The Economics of International Integration. Northampton: Edward Elgar Publishing.

33. Kara, Ş. (1996). Ekonomik Entegrasyon Teorisi, İstanbul.

34. Karame, G. \& Androulaki, E. (2016). Bitcoin and Blockchain Security. Norwood: Artech House Publishers.

35. Kerr, W. \& Gaisford, J. (2007). Handbook on International Trade Policy. Northampton: Edward Elgar.

36. Keynes, J.M. (1931). Economic Possibilities for our Grandchildren. J. M. Keynes, In Essays in Persuasion (s. 321-335). New York: Palgrave Macmillan.

37. Kızıltan, A. \& Sandalcılar, A.R. (2011). Türkiye'nin Dış Ticaretinde Ekonomik İşbirliği Teşkilatı'nın (ECO) Yeri ve Önemi, Avrasya Etüdleri, (38), 99-122.

38. Lee, Y.W. (2012). Network effects on international trade, Economics Letters, 116(2), 199-201.

39. Maier, R. (2007). Knowledge Management Systems. Berlin: Springer.

40. Mbogo, A. (2018). Africa to Adopt Blockchain for New Digital Free Trade Area, Bitcoin Africa, https://bitcoinafrica.io/2018/02/28/africato-adopt-blockchain-for-new-digital-free-trade-area/03/07/2019. 
41. Meijers, H. (2014). Does the Internet Generate Economic Growth, International Trade, or both?, International Economics and Economic Policy, Springer, 11 (1), 137-163.

42. Neetu, Y. (2014). Total Interpretive Structural Modelling (TISM) of Strategic Performance Management for Indian Telecom Service Providers, International Journal of Productivity and Performance Management, Emerald Group Publishing, 63(4), 421-445.

43. Öz, E. (2018). Büyük Finansal Tufan. İstanbul: Şira Yayınları.

44. Petry, C.F. (2008). The Cambridge History of Egypt. Cambridge: Cambridge University Press.

45. Rifkin, J. (2014). The Zero Marginal Cost Society: The Internet of Things, the Collaborative Commons, and the Eclipse of Capitalism. New York: St. Martin's Press .

46. Singhal, B., Dhameja, G., \& Panda, P. (2018). Beginning Blockchain: A Beginner's Guide to Building Blockchain Solutions . New York: Apress.

47. Sundararajan, A. (2016). The Sharing Economy: The End of Employment and the Rise of Crowd-Based Capitalism. Cambridge: The MIT Press.

48. Sanlı, B. (2008). Ekonomik Entegrasyon Teorisi Çerçevesinde Avrasya Birliği’nin Olabilirliği, Iktisadi ve Idari Bilimler Dergisi, Cilt: 22 Ocak 2008 Sayı: 1.

49. Timmis, J. (2012). The Internet and International Trade in Goods, Discussion Papers 12/08, University of Nottingham, GEP.

50. Uyar, S. (2007). Ekonomik Bütünleşmeler ve Gümrük Birliği Teorisi. http:// www. econturk.org/dtp13.htm, (29.06.2007), 1-14.

51. Y1ldırım Ertuğrul (2005). Gümrük Birliği ve Rekabet: Türkiye Uygulaması. Published Master Thesis, Zonguldak.

52. Yiğit, M. (2003). Ekonomik entegrasyon, Beta Yayınları, İstanbul.

53. Yurtsever, H. (2010). Uluslararası Ödeme Şekillerinde Bankalarca Alınan Komisyon ve Vergi Üzerine Eleştirel bir Yaklaşım. Ege Academic Review, İzmir.

54. Yüksel, S., Dinçer, H., \& Meral, Y. (2019). Financial Analysis of International Energy Trade: A Strategic Outlook for EU-15. Energies, 12(431), 1-22. 